\title{
EFFECT OF MAGNETIC PLATE IN MEMORY OF RATS
}

\author{
(Effect of magnetic plate in memory of rats)
}

\author{
Neuza Maria Ferraz de Mello Gonçalves ${ }^{1}$ \\ Adriane Granato Bardal ${ }^{2}$ \\ Lincon Bordignon Somensi ${ }^{3}$ \\ Neliza Ferraz ${ }^{4}$
}

\footnotetext{
1 Professora Titular da Disciplina de Bioquímica da Pontifícia Universidade Católica do Paraná e do Centro Universitário Campos de Andrade. $\mathrm{Dr}^{\mathrm{a}}$ em Ciências pela Universidade Federal do Paraná. PhD em Agressões ao Organismo. - Kobe-University-Japan.

Email: neuzafmg@hotmail.com. (41) 9876-1331, 3016-1331. Curitiba-PR.

2 Nutricionista. Centro Universitário Campos de Andrade.

${ }^{3}$ Farmacêutico e Mestre em Ciências Farmacêuticas - Universidade do Vale do Itajaí-

${ }^{4}$ Neliza Ferraz - Design de Produtos e Arquiteta-Pontifícia Universidade Católica do Paraná.
}

RESUMO: Entende-se como magnetismo, o processo físico que ocorre entre dois polos opostos de um ímã e a ciência desse fenômeno que ocorre no ser, magnoterapia. Neste contexto, preocupado com a diminuição magnética, os pesquisadores iniciaram estudos sobre o uso de terapias para restaurar a saúde ao nível celular e energia de substituição que o corpo precisa para se reabilitar da agressão do meio ambiente. O objetivo deste estudo foi avaliar o efeito do quadro magnético em relação à memória de ratos, Wistar (Rattus norvegicus var albinos), por períodos de 5, 10 e 20 minutos em um compartimento especial, chamado de labirinto. Justifica a importância deste trabalho, a avaliação do conteúdo de memória quando utilizar a placa magnética no processo de conhecimento é codificada, retida e posteriormente recuperada, mas devido ao estresse da vida agitada nos dias de hoje, o homem está diminuindo a sua memória e seu impulso de energia. A metodologia refere-se às avaliações dos ratos em busca de memória alimentos após o curso de vários compartimentos. Os resultados encontrados na observação com os 12 ratos, o grupo experimental, em um período de 20 minutos com a placa magnética e a percentagem de respostas correctas with $\leq 12$ tempo de permanência dias placa são significativamente diferentes da porcentagem de acertos de placa ratos tempo de permanência $>12$ dias. Portanto, estatisticamente confirmou que o cartão magnético foi eficaz nesses camundongos memória em busca de comida, mas não houve diferença estatística nos tempos de observações 5 e 10 minutos em grupos experimentais.

Palavras-chave: magnetismo, experimental, efeitos

ABSTRACT: It is understood as Magnetism, the physical process that occurs between two opposite poles of a magnet and the science of this phenomenon that takes place in being, Magnotherapy. In this context, concerned about the magnetic decrease, the researchers initiated studies on the use of therapies for restoring health to the cellular level and energy replacement that the body needs to rehabilitate itself from aggression from the environment. The objective of this study was to evaluate the effect of the magnetic board in relation to the memory of rats, Wistar (Rattus norvegicus var albinos), for periods of 5, 10, and 20 minutes in a special compartment, called the labyrinth. Justifies the importance of this work, the 
evaluation of the memory content when using the magnetic board in the process of knowledge is encoded, retained and later recovered, but due to the stress of busy life nowadays, man is decreasing your memory and your energy boost. The methodology refers to the evaluations of the rats in search of food memory after the course of several compartments. The results found on the observation with the 12 rats, the experimental group, in a period of 20 minutes with the magnetic board and the percentage of correct answers with $\leq 12$ days plate dwell time are significantly different from the percentage of correct answers of mice plate length of stay $>12$ days. Therefore, statistically confirmed that the magnetic card was effective in these mice memory in search of food, but there was no statistical difference in the times of observations 5 and 10 minutes in experimental groups.

Key Words: Magnetism, experimental, effects 


\section{INTRODUCTION}

According to Baruch scientists; (1972) and Quevedo (1979) the magnetic effect is responsible for transforming the land into an immense magnetic block, suggesting that occurs issuing such rays to mankind. So to assess the effects of this process, the promotion of health and well-being, or, in the recovery of magnetism ratios, the therapeutic magnets is used, recognized by the Food and Drug Administration FDA and recommended by the World Health Organization - WHO.

With the concepts of the importance and effects of non-ionizing radiation (ultraviolet and infrared) on mankind, one realizes that the rates are decreasing in relation to the high increase in demand of farmers into the city, the demand for more and better economic structure (RIPKA, 2001). It is also aware that decades ago, the man was influenced to participate and interact advances in the fields of Biological and Technology, such as the discovery of penicillin, the "genetic engineering". However this research, led man to stay several hours in closed and isolated from the solar radiation and the physical contact with the earth (Mc.COMB, 1966).

Another important factor was the freedom of man in search of comfort and well-being, seizing elements that provide magnetism, such as concrete building blocks for roads, buildings and the manufacture of cars, reducing this way the contact with the earth and consequently a percentage of energy stimulus that was transmitted to him by the magnetic block (GONÇALVES, 2005).

In urban life, the man started an occupation more cloistered, that is enclosed in four walls, tall buildings and for your comfort, began to use rubber or plastic footwear. In line with the pace of a modern city, with accumulation of vehicles and pollution, accelerated this way, the process of loss of non-ionizing radiation, for humanity (LEBORGNE, 1964).

Combined with other factors such as contamination of the vapors of the plants, the use of pesticides and food contaminated with the deforestation of large areas, have also contributed to the decrease in magnetic indices. (GONÇALVES, 1995). It is essential to emphasize that as a result of population increase man has positioned itself strongly in the deforestation process to increase agricultural production, participating, so the process of changing the natural ecosystem. Therefore, allowed space to environmental attacks by pests and weeds, which compete with crops for the physical space, nutrients and the own solar power (GONÇALVES, 1996).

It is important to note that in relation to physics, radiation can be considered and encompassed under a single concept "radiant energy ", but under the biological aspect, one can regard them as "stimulus". It is necessary that man understands the effects and importance of these radiations to activity of the human body. However, with all these aggressive factors in metabolic rate over the years the man is reducing its energy, combined, yet the consequences of magnetic shortage (GONÇALVES, 2005).

Concerned therefore with the magnetic decrease, several researchers have begun to intensify their studies on magnotherapy. The Indians were the pioneers, followed by Chinese, but it was the Japanese who are dedicated and thoroughly highlighted his research for over 30 years. But all start from the same conclusion: the magnetism has the specific task of balancing the energies that are lost with the wear and tear of modern life. Consequently interfere in any biological 
mechanism of man that is in all of their motor skills (GONÇALVES, 2005).

This work began on the knowledge that the magnetic action in relation to memory, allow coding, retention, and subsequent recovery. But this process is complex, since there are several different types of memory retention, and that certain brain regions are most important for some types of retention than in others. The objective of this study was to evaluate the effect of the magnetic board in relation to the memory of Wistar rats (Rattus norvegicus var albinus) over a period of 5,10 and 20 minutes, in search of food in a maze of compartments.

\section{MATERIAL E MÉTODOS}

For the experimental evaluation were used adult rats, bred in the animal house of the Catholic University of Paraná. The animals were kept in proper environment in temperature and natural light, with power probitorio feed $(G)$ Produtor Mill Primor S/A and water "ad libitum" for a week in order to eliminate possible changes that may occur in relation to health and eventual loss of the animals in the experimental route. This work is part of the Research Group Directory, titled "Biochemical Study Group and Experimental Biology - 2012.

The procedures regarding the handling of the animals were performed in accordance with the principles and rules documented in the "Animal Care Principles" and "Ethical Principles of Animal Experimentation" the Brazilian College of Animal Experimentation and Ethics at the Catholic University Committee Paraná.

In all, this study, we used thirty (30) animals, with six (6) for the master plan and 24 (twenty four) for research as a whole. The pilot plan was drafted for the training of the technique used in this study.
MAZE

The research was incorporated in behavioral assessments and memorization of mice, searching for food in a physical space called "Labyrinth", consisting of two areas containing the main corridor and a secondary with 7 identical compartments, some dead, mobilizing the animal to search for new compartments.

In the last room, located in the area, the left central door, is the food and the right, also in the last compartment, a shock device.

It is important to inform that the number, spacing of the compartments are complex, and some have no way out, causing the animals to memorize the process of return and follow the drive for a new magazine. The final process is the memorization of the hall, which contains the last compartment, the food, which should be found after attempts of trial and error, between the various compartments of the aisles.

The maze, the film has a length of $1.77 \mathrm{~m} 2$ by $1.11 \mathrm{~m} 2$ wide, having a single central port, and from this , divided into two (2) areas, seven (7) identical physical spaces for each area. All part of experimental observation was shot with Cyber - shot machine Sony brand.

\section{MASTER PLAN}

The master plan was conducted with six (6) mice, three (3) for the experimental group and three (3) for the control group (placebo). The procedure is documented method used, according to the technique described in the item of the experimental groups.

After the passage of each experimental animal, the maze was thoroughly cleaned with ethanol solution of $10 \%(\mathrm{v} v)$ and dry with paper to avoid interference odorous signals in different 
compartments and possible doubts about the results, prevention also studies established in Wallace et al (2002) 10.

\section{EXPERIMENTAL GROUPS}

All rats were subjected to fasting for 12 hours of food, only receiving water. After observing the movement of normal, healthy mice in these cages, the animals were eligible for this study.

In this research were considered 24 (twenty four) rats divided into two groups: experimental group, consisting of twelve (12) mice with a magnetic plate attached to the abdomen and the control group (placebo) to twelve (12) mice without the magnetic board. Then there was the beginning of observation in the maze, which provided a choice between areas and their respective compartments, coming to food or an electric shock.

The experiment was conducted with each rat during three (3) different periods of time and independent: five (5), ten (10) and twenty (20) minutes to rest 30 (minutes) between the observation periods.

They were filmed and recorded the number of times, at intervals of scheduled times, in which individual animals traveled the two identical areas (compartments) to find the last compartment, where there was food.

The variable of interest in the study was the percentage of correct answers, ie the percentage of times that the animals found food. As the plate is fixed in rats of the experimental group seven (7) days before the evaluation, and each day, the evaluation was performed with a mouse of each group, so the time of plate residence was not the same for all rats. Thus, the time variable board stay was also recorded, as important data for research.

This study aimed to evaluate the sensitivity, the behavior in relation to different compartments, as well as the memory capacity of the different mice, compared to runners left and right, the food and shock device (fire) in these times (Figure 1).

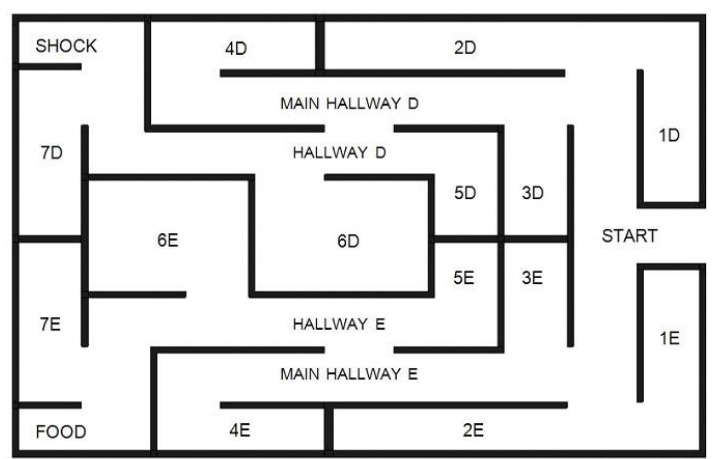

Figure 1 - Labyrinth. The maze consisted of the following feature: $1.77 \mathrm{~m}^{2}$ and $1.11 \mathrm{~m}^{2}$ length wide, divided into two areas with 7 compartments.

\section{STATISTICAL ANALYSIS}

The results of the experiment were expressed as means and standard deviations of the percentage of correct animal. For comparisons between groups used the nonparametric MannWhitney, considering a value of $p<0.05$ statistically significant (SIEGEL, 1956).

\section{RESULTS AND DISCUSSION}

The Pilot Plan was satisfactory for technical training, observation, training, and possible appropriate changes to achieve better results. Preventions also used in research (RODGERS et al., 1996).

\section{Residence Time Sing and Hits Percent}

For the experimental group, we tested the null hypothesis that the percentage of correct answers for the mice with residence time of the plate $\leq$ 12 days was equal to the percentage of 
correct answers to the mice with board length of stay $>12$ days, versus the alternative hypothesis of different percentages. The results of averages, standard deviations and $\mathrm{p}$-values are presented in the table in Table 1.

Table 1 - Percentage of standard deviations and $p$-values in observation periods of 5 , 10 and 20 minutes of magnetic plate in the abdomen of rats.

\begin{tabular}{cccc}
\hline $\begin{array}{c}\text { Observation } \\
\text { period }\end{array}$ & $\begin{array}{c}\text { Mice with time } \\
\text { Plate } \leq \mathbf{1 2} \text { days }\end{array}$ & $\begin{array}{c}\text { Mice with time } \\
\text { plane }>\mathbf{1 2} \text { days }\end{array}$ & Value of $\boldsymbol{P}$ \\
& $\begin{array}{c}\text { Hit percentage } \\
\text { Média } \pm \text { SD }\end{array}$ & $\begin{array}{c}\text { Hit percentage } \\
\text { Média } \pm \mathrm{SD}\end{array}$ & \\
5 minutes & $73.75 \pm 7.94$ & $77.61 \pm 8.30$ & 0.2403 \\
10 minutes & $86.08 \pm 1.67$ & $88.80 \pm 2.43$ & 0.0649 \\
20 minutes & $92.60 \pm 2.10$ & $95.69 \pm 0.97$ & 0.0152 \\
\hline
\end{tabular}

The results of the statistical tests document that in observation for a period of twenty (20) minutes, the percentage of correct answers of mice with time $\leq 12$ days board stay are significantly different from the percentage of correct answers with board length of stay $>12$ days. There were no significant differences when the mice were observed for five (5) or ten (10) minutes.

\section{Experimental Group comparison with the control (placebo)}

For each observation period, we tested the null hypothesis that the percentages are the same for both groups, versus the alternative hypothesis of different percentages. The results are shown in figure 2 and table 2 on the chart.
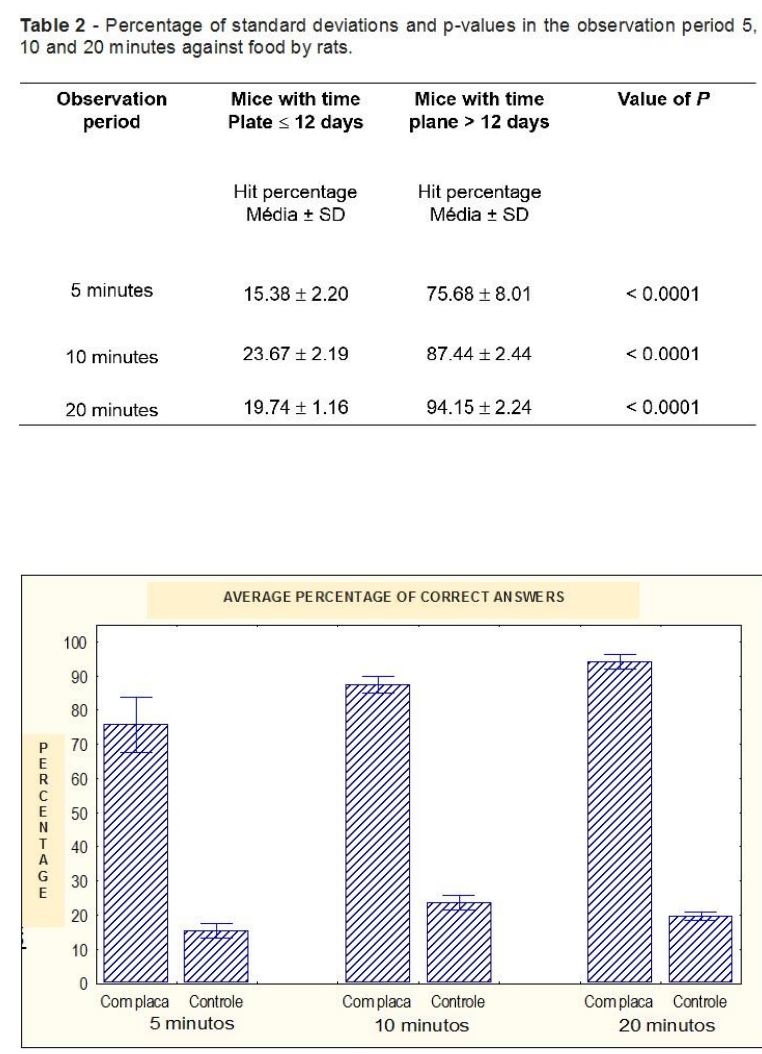

Figure - 2 Representation of the average percentage of correct answers of mice in finding food, on observations of 5,10 and 20 minutes.

It was observed that mice in the experimental group, i.e. with the magnetic plate in times of five (5) and ten (10) minutes showed a statistically absence of memorization of the two areas and compartments until they find the food or fire. It is certainly the viewing time, knowledge, stability and comfort to go through the maze of different spaces, this is the time to adapt the first 5 (five) minutes.

One can explain this phenomenon, the understanding that learning, or memory obtained in the first time, that the five (5) minutes would lead to a change in behavior in the second half, that is to ten (10) minutes. It is important to mention that there were thirty (30) minute break, the trial of a mouse to another in the passage of the runners (primary and secondary) between the different times 5, 10 and 20 minutes. This Care stuck in prevention, to avoid the permanence of any type odor in the different compartments, which could encourage the direction of 
Effect of magnetic plate in memory of rats

the route of choice for the different compartment. Therefore, it is clear that the results are focused on the memory of each mouse, excluding the possible and random interference.

It is important to document that this time interval, of each trial could hamper memorizing the maze. Rodgers and Shepherd (1997) found similar observations.

The time of twenty (20) minutes, was specific for establishing this apprenticeship, since it was observed that the reduction of 5 times (five) and ten (10) minutes, was not sufficient for operation, observation and memorizing the maze, this is about the different compartments and access to two runners, and in some bays there is no output, leading to a loss in learning, given these that are in accordance with documented by (DALCÓL et al., 2003).

Therefore, it is considered that the optimal time for memorization was twenty (20) minutes, but cannot rule that the repetition of 5 times (five) to 10 (ten) produced an adaptation to the full memory, which was statistically similar to 20 (twenty) minutes.

\section{CONCLUSION}

Magnetism is the process of natural excitation that promotes the human organism welfare one stable relationship with its environment, but due to this magnetic shortage, the human body uses very little selfdefense. Thus, in many cases, the man contracted muscle pain, eye wear, back pain, muscular rigidity, shoulder tension, low back pain and body aches, etc.

It is understood that humanity is only the beginning of understanding the relationship between biology and the geomagnetic field, as well as the electric and magnetic forces intrinsic and extrinsic to the body or in a more complex understanding of what information they would be carriers.

It is believed therefore that in the near future, the electromagnetic fields will be used in medicine where the biochemical means or even the understanding of this metabolic relationship, cannot position yourself as a whole.

The results found on the observation with rats at a period of 20 minutes with the magnetic board and the percentage of correct answers by rats with time $>12$ days board stay are significantly different from the percentage of correct answers of mice with residence time of Board $>12$ days. Therefore, statistically confirmed that the magnetic card was effective in these mice memory in search of food in a complex compartment called labyrinth. Yet the prevention and experimentation election with 30 intervals (thirty) minutes stopped, the principle that two or more mice could run through the maze simply by browsing segments, among them, not memorizing the maze of compartments.

We conclude with certainty that there was no statistically difference in the times of observations 5 and 10 minutes in experimental groups.

\section{NOTAS INFORMATIVAS}

This work is part of the Research Group Directory, titled "Biochemical Study Group and Experimental Biology 2012.

\section{REFERÊNCIAS}

1 BARUCH, P. Magnètisme, Paris. Hermann, 1972.

2 QUEVEDO, C.P. Eletromagnetismo, São Paulo, MC Grew-Hill do Brasil, 1979, p. 353

3 Food and Drug Administration - FDA and recommended by the World Health Organization $-\mathrm{WHO}$ 
4 RIPKA, P. Sensores and magnetometer, Boston, Artech, House, Boston-London, 2001, p. 493-494.

5 Mc.COMB., H. Magnetic observatory manual. Washington, U.S. Government Printing Office, 1996, p. 232.

6 GONÇALVES, N.M.F.M. Magnoterapia, EISEI DO BRASIL, 2005, p. 1-36.

7 LEBORGNE, M. Déterminations magnétiques et champs magnétique terrestre. $M$. Leborgne Paris; Institut Géographique National, 1964, p. 104.

8 GONÇALVES, N.M.F.M. Propriedades do herbicida Paraquat. Rev. Acad. 1995 V. VI no 11, p. 45-48.

9 GONÇALVES, N.M.F.M. e CARVALHO, A.M.H. Análise do Herbicida Paraquat em amostras de urina e batata. Arch. Vet. Scienc. UFPR; Outubro 1996, V.1, p.65-66.

10 WALLACE, D. G.; GORNY, B.; WHISHAW, I. $Q$. Rats can track odors, other rats, and themselves: implications for the study of spatial behavior. Behavioral Brain Research, 2002 v. 131, p. 185-192.

11 SIEGEL, S. Nonparametric statistics. New York: McGraw-Hill Book Company, Inc., 1956.

12 RODGERS, R. J.; JOHNSON, N. J. T.; HODGSON, T. P. Resistance of experientially induced changes in murine plus-maze behavior to altered retest conditions. Behavioral Brain Research, 1997 v. 86 p 71-77.

13 DAL-CÓL, M. L. C. et al. Lack of midazolaminduced anxiolysis in the plus-maze Trial 2 is dependent on the length of Trial 1. Pharmacology, Biochemistry and Behavior, 2003, v.74, p. 395-400. 